\title{
LITIGATION AND ITS CURRENT ROLE IN TOBACCO REGULATION IN AUSTRALIA
}

\author{
Jonathan Liberman \\ VicHealth Centre for Tobacco Control \\ The Cancer Council Victoria
}

\section{INTRODUCTION}

Litigation plays an important role in tobacco control, both in Australia and overseas. Though it is often portrayed as being about no more than a battle between a plaintiff and a defendant over money, litigation in fact performs a major regulatory function.

While litigation can take many forms — such as a damages claim by a private individual, a criminal prosecution by the state, or enforcement of legislation by a statutory agency such as the Australian Competition and Consumer Commission - a court will only find for a plaintiff if a defendant is found to have acted unlawfully or breached a legal obligation.

Successful legal action brings the defendant to account, and provides the opportunity for remedy, whether in the form of compensation to a person who has suffered, punishment of the wrongdoer, or the granting of injunctions (such as an order that a person or corporation refrain from certain conduct or that it undertake corrective action to set its wrongdoing right). Ultimately, it is litigation, or the threat of litigation, that compels individuals and corporations to comply with their legal obligations. This article summarises the current state of tobacco litigation in Australia as of January 2004.

\section{ENVIRONMENTALTOBACCO SMOKE LITIGATION}

Litigation over the harm caused by environmental tobacco smoke has been an important catalyst in the move towards smoke-free venues. Successful cases include an action against the Tobacco Institute of Australia for misleading and deceptive conduct by the publication of an advertisement about environmental tobacco smoke, ${ }^{1}$ and claims by individuals against employers and occupiers of public venues in negligence (that is, breaches of duty of care): under occupiers' liability legislation; under antidiscrimination legislation; for breach of contract; and under workers compensation legislation. ${ }^{2}$ News and other coverage of these cases has been significant in publicising the dangers of environmental tobacco smoke, in reminding employers and occupiers of public venues of their obligations to provide safe and healthy workplaces and venues, and in bringing powerful insurance considerations into play for employers and occupiers of public venues.

\section{THE McCABE CASE}

In Australia, litigation against the tobacco industry over the harm suffered by smokers is still in its infancy. The best-known case, McCabe v. British American Tobacco Australia, which has received international attention through its revelations of document destruction by British American Tobacco Australia, is currently before the Supreme Court of Victoria. ${ }^{3}$

The plaintiff in the McCabe case, Rolah McCabe, was a 51 year-old woman dying of lung cancer. She sued British American Tobacco Australia for negligence, alleging that it had-while knowing that cigarettes were addictive and harmful to health: targeted children in its advertising; taken no reasonable steps to reduce or eliminate the risks of addiction and disease; and ignored or publicly disparaged research results that demonstrated the harms of smoking.

In March 2002, the trial judge, Justice Eames, struck out British American Tobacco Australia's defence to the action and ordered judgment for Ms McCabe, after finding that the process of document discovery was subverted by the defendant and its solicitor with the deliberate intention of denying a fair trial to the plaintiff. ${ }^{3}$ According to Justice Eames, this subversion involved: the deliberate destruction of thousands of relevant documents to keep them from prospective plaintiffs such as Ms McCabe; misleading the court about what had become of the missing documents; and the ongoing 'warehousing' of documents to keep them from the court. Justice Eames sent the case to trial before a jury solely on the issue of quantum of damages. The jury awarded Ms McCabe $\$ 700,000$.

In December 2002, a few months after Ms McCabe's death, the Victorian Court of Appeal overturned Justice Eames' decision and sent the case back to trial. The Court of Appeal overturned a number of Justice Eames' findings of fact, including those about the purpose of British American Tobacco Australia's document destruction policies and practices. ${ }^{3}$ There was no dispute before the Court of Appeal that British American Tobacco Australia had destroyed thousands of documents at a time when it anticipated litigation of the sort brought by Ms McCabe, but the Court of Appeal established a new legal test to determine the significance of the destruction. On 3 October 2003, the High Court of Australia refused Ms McCabe's estate special leave to appeal against the decision of the Victorian Court of Appeal. It also refused the applications of the New South Wales and Victorian Attorneys-General to intervene in the High Court application. This means that the case is now back before 
the Victorian Supreme Court for hearing. If they choose to proceed with the case, Ms McCabe's family can either pursue the negligence action with a full hearing of the issues, or make another 'strike out' application based on document destruction. However they choose to proceed, the family faces a substantial order for costs as a result of the decision of the Victorian Court of Appeal.

The McCabe case has had major implications. The NSW Government has addressed issues of lawyers' involvement in document destruction in the NSW Legal Profession Regulation 2002. ${ }^{4}$ The Victorian Attorney-General is investigating whether legislation is required to deal with circumstances of the kind revealed in the McCabe case, in light of the effect that document destruction can have on the administration of justice. In addition, the United States Department of Justice has incorporated the revelation of document destruction into its litigation against the tobacco industry within the United States. It has asked Mr David Schechter, a former President of British American Tobacco (United States), questions under oath about document destruction. ${ }^{5}$ It is presently seeking to have Mr Nicholas Cannar, a former lawyer for British American Tobacco and now a Sydney resident, answer questions about British American Tobacco's international document destruction policies and practices. The United States Department of Justice's application to require Mr Cannar to answer questions was granted by the Supreme Court of New South Wales in October 2003. ${ }^{6}$ If the United States Department of Justice continues to pursue the document destruction issues in its litigation, it is likely that more of the document destruction story will unravel, with consequences for future personal injury cases both in Australia and overseas.

In addition to the consequences for civil litigation, there is also the potential for criminal charges for offences such as attempting to pervert the course of justice.

\section{THE CAUVIN CASE}

Another case currently underway against the tobacco industry in Australia is Cauvin v. Philip Morris Limited and Others in the Supreme Court of New South Wales. The plaintiff, Myriam Cauvin, is a 41 year-old woman who contracted emphysema and required lung transplant surgery. Ms Cauvin has sued Philip Morris and British American Tobacco for misleading and deceptive and unconscionable conduct under the Commonwealth Trade Practices Act 1974 and the NSW Fair Trading Act 1987.

Ms Cauvin is not only seeking compensation. She is also seeking: that certain documents be disclosed to public health or regulatory authorities; that corrective statements to be made concerning the health risks and addictiveness of smoking; funding of public education and smoking cessation programs; and establishment of a fund to provide compensation to other people who are likely to suffer as a result of the tobacco industry's conduct, including the cost of medical treatment.

Ms Cauvin claims that Philip Morris and British American Tobacco engaged in: conduct to promote the benefits and pleasures of smoking and deny or minimise the risks of addiction and disease, including the advertising, marketing and promotion of cigarettes as enhancing the life and enjoyment of consumers; promoting certain brands of cigarettes, such as light, mild, and low-tar, as less harmful than others; making public statements denying the existence of reliable evidence concerning the health risks and addictiveness of smoking; lobbying the federal and state governments to desist from taking actions likely to be effective in reducing smoking related disease; and intentionally concealing knowledge of the association between smoking and nicotine addiction and smoking and disease. ${ }^{7}$

\section{CONCLUSION}

Because of differences between the legal systems of Australia and the United States, Australia is unlikely to see litigation against the tobacco industry on the scale brought in the United States. Nonetheless, litigation will continue to be an important strategy to reduce the harm caused by smoking. This should not be surprising. Every day, in courtrooms around the world, individuals or corporations who have acted unlawfully or failed to discharge their legal obligations are brought to account for their conduct. The process of bringing them to account allows society to obtain appropriate remedies, and plays an important role in influencing, changing, and ending conduct that causes harm. In the case of tobacco, public health and justice considerations can come together in the courtroom, with results that significantly further the interests of both.

\section{REFERENCES}

1. [1991] ATPR 41-07 www.austlii.edu.au/cgi-bin/disp.pl/au/ cases/cth/federal\%5fct/unrep4662.html; on appeal (1992) 111 ALR 61) www.austlii.edu.au/cgi-bin/disp.pl/au/cases/cth/ federal\% 5 fct/unrep6037.html.

2. 'When smoke gets in your eyes ... nose, throat, lungs and bloodstream: A guide to passive smoking and the law in NSW. Appendix A. Available online at www.nswcc.org.au/ editorial.asp?pageid $=1390$.

3. [2002] VSC 73 (22 March 2002) www.austlii.edu.au/au/cases/ vic/VSC/2002/73.html; on appeal [2002] VSCA 197 (6 December 2002) www.austlii.edu.au/au/cases/vic/VSCA/ 2002/197.html.

4. Legal Profession Regulation 2002 (NSW), Regulation 142A.

5. Portions of the transcript of the deposition are available at http://tobacco.health.usyd.edu.au/site/supersite/resources/ pdfs/schecter_deposition_excerpts.pdf.

6. [2003] NSWSC 802 (8 October 2003) http://caselaw. lawlink.nsw.gov.au/isysquery/irl37cc/2/doc.

7. [2003] NSWSC 1225 (19 December 2003) http://caselaw. lawlink.nsw.gov.au/isysquery/irl37ba/4/doc. W 